\title{
Impact of Demonetization on Employment in India: Issues and Challenges of Labour Market
}

\author{
Nida Fatima \\ Post Doctoral Research Fellow, ICSSR, \\ Department of Political Science, Aligarh Muslim University, Uttar Pradesh, India \\ E-mail: fatimanida2419@gmail.com
}

\begin{abstract}
Demonetization is a conventional practice in monetary policy to embark upon black money. However, it was meant to be suddenly implemented. Long-ago, demonetization has taken place twice but it failed because the idea is to tackle the black money existing in circulation. This wasn't for tackling corruption that's what Government is not saying that $100 \%$ corruption will be tackled and also if announcement and time would have been given, this step might not have been successful in controlling black money and counterfeit currency in circulation coming from Pakistan, Nepal or other countries. Demonetization is a course of extraction of an exacting form of currency from circulation. The existing form of money has chosen from transmission and retired, to be put back with new notes or coins. The newest demonetization measures taken by the Indian Government on November 8th 2016, in an attempt to hold back corruption and black money has resulted in a massive amount of involuntary consequences. While the key objective following this budge is commendable, the planning and implementation of the scheme left much to be required from a policy point of view. This step has caused rolling impact throughout the economy, departing the most sectors reasonably crippled owing to the unanticipated cash crisis. The labour market in India has been witnessing numerous uncertainties including the problem of world recession, and growing 'automation' particularly in the manufacturing sector. More precisely, in the last one and a half decade, India has emerged a global power in terms of the development or diffusion of new technology in the form of ICT. ICT intensity, defined as the ratio of ICT investment to non ICT investment, has increased significantly across industries led to 'automation' in most production (and distribution). Its impact on productivity led growth, and direct employment is well documented. However, its negative employment impact, particularly in the ICT using manufacturing sector has largely been ignored. So, in a situation, when the debate, whether the net employment impact of ICT on the economy as a whole is positive, is still unconclusive; any major policy change like 'demonetization' is likely to make the employment scenario further volatile by causing uncertainties to rise in labour market, mainly the informal employment.
\end{abstract}

Keywords: Demonetization, Employment in India, Labour Market

\section{INTRODUCTION}

For employment growth, economic growth is one of the important factors. In a situation, when the recession phase caused by global crisis of 2009 had hardly dimmed away, the recent move of 'demonetization' will push growth downward as predicted by most economic agencies including RBI and IMF. The prediction of decline in GDP ranges from $0.5 \%$ to $2 \%$. Supposedly, a unit turn down in growth rate results a decline in employment growth rate, a concept called as employment elasticity (EE) of output. Consequently, labour market, particularly informal in nature, will be most affected by the move. The extremely well turned-out budge of declaring Rs 1000 and Rs 500 denomination currency notes to restrain the threat of black money, corruption, forged currency and economic terrorism is commendable and visionary and put up with a host of political and economic reimbursement in the long run. The instantaneous consequence is that of absolute disorder as $86 \%$ of the economy became obsolete as an instantaneous upshot post declaration at midnight. The budge has caused ripple effects in various sectors leaving them crippled outstanding to unexpected liquidity critical situation, this constrain impacted both organised and unorganised sectors as well as the overall economic foundation of the nation.

The formal and informal sectors that were already struggling with depressed stipulation and low down investment are now seeing job cuts and hiring freeze up. The Report on Fifth Annual Employment and Unemployment Survey (2015-16), a couple of points are worth mentioning. First, among all, very few households (20 \%) with monthly income less than or equal to Rs. 10,000 have bank account. Seconds, majority of workers belong to this income group only; $82 \%$ among selfemployed, $60 \%$ among regular or salaried workers, $87 \%$ among contract workers, and 96 percent among casual workers. Third, majority of workers, in all categories of employments have no written contract, $65 \%$ (regular workers), 68 percent (contract workers), and $95 \%$ (casual workers). Fourth, majority of workers $(71.2 \%)$ receive no social benefits. Fifth, $60 \%$ of workforce belongs to just six states, Tamil Nadu, Maharashtra, Andhra Pradesh, Gujarat, Karnataka and Uttar Pradesh [1].

Informal employment, which comprise as high as $95 \%$ of all employment is backed with no (or least) social security such as health, education or provident fund benefits. Workers are subject to be fired (or lay-off) at any point of time during the production (or distribution) process. Since majority of wage payment is made in cash form; they are thus the ones to face misery caused by the recent 
announcement of 'demonetization.' [2]. Additionally, a point worth mentioning is that, all employment in the formal sector is not formal per se; rather informal in nature, i.e. not backed by social security. It rose from 38.7 percent to 46.6 \% during 2000 to 2005, or a phenomenon known as 'infomalization of the formal sector' (NCEUS, 2009) or social security as percentage of the value of output in the formal sector has recorded a perceptible declined, from 14 $\%$ in 2000 to $10 \%$ in 2013. So, if output growth declines by the recent policy of de-monetization, as predicted by most economic agencies including World Bank, employment of largely these informal workers will be affected.

Further, using the same data source, in the last ten years since 2003, a total of 94163 additional factories gave rise to nearly 4 million employment generations; or 41 workers per factory. So, it is easy to infer, if de-monetization' led a factory shuts down; it will render nearly 41 people unemployed. Moreover, from the sectoral analysis of industries within the manufacturing sector a couple of points also are worth mentioning [3]. Further, using the principle of employment elasticity (EE), an attempt is made to estimate likely impact of 'demonetization on employment in the organized manufacturing sector of India.

Over the past half a decade, owing to numerous reasons including ICT led automation; employment elasticity has declined perceptibly in most industries. Employment elasticity, by definition, measures percentage change of labour demand (or employment) due to a percentage change in output level. In short, it measures the employment intensity of a unit of output produced. The extent of employment loss due to an expected demonetization led decline in output growth rate [4].

\section{OBJECTIVES OF THE STUDY}

1. The aim of this paper is to study the previous instances of demonetization

2. To evaluate consequences of demonetization on labour market

3. To analyze the impact of demonetization on employment in India

4. To study reasons behind the current demonetization move

5. To study the impact of demonetization on jobs and employment specifically.

6. To study the future repercussions of this move.

\section{RESEARCH METHODOLOGY}

The present study entitled "Impact of demonetization on employment in India: Issues and challenges of Labour market" is a topic that requires both the exploratory (based on secondary data) as well as descriptive (based on primary data) studies but current study is based on secondary data analysis and will examine secondary data collected from recent books, websites, blogs, research papers and reports of government. The effect of demonetization on employment and labour market will be highlighted in paper.

\section{DEMONETIZATION AND UNEMPLOYMENT}

According to Economic Survey (2013-14), for the country as a whole it is also found that the employment impact of de-monetization is not uniform across industries. More precisely, labour intensive industries such as food, textile, wearing apparel, leather and leather product industries are seemed to have witnessed the major loss [5].

India is also largely a cash economy. The cash dealings in this economy are far more than the total number of electronic transactions done on a daily basis. People are facing problems because the limit of withdrawal has not been kept at a higher level. The Indian economy sooner than demonetization was already struggling with slow demand, investment and slow production too. The IP slipped down to $1.9 \%$ in Oct compared to an expansion of $9.9 \%$ in similar period preceding year and this happened as a result of jaded performance of manufacturing sector and a decline in production of capital goods. Manufacturing sector contracted by $2.4 \%$ in October and capital goods output reflected a tightening of $25.1 \%$. After Demonetization there is additional decline in the economy- all sectors from manufacturing to service have been unfavourably affected. Renowned sectors like automobile, real estate and infra have been poorly hit and witnessed off-putting job growth, eventually the sales of large equipment and machinery in rural areas dropped by a long way cutting down jobs in the phase of note ban [6].

Small farmers, sellers, merchants, daily wage labourers and traders are suffering because of lack of proper planning, intelligence and foresight such as recalibration of ATM machines. Employment in organized sectors was likely to be largely impassive if the demonetization is handled adroitly by govt. and does not take too long. If the demonetization does not keep pace as promised and by December end cash is still difficult to come by then the organized sector will also see layoffs. A close to total liquidity compressed on the purchasing power of people will lead to a slowdown in sales of every product and service. Above and beyond people will get used to getting by with less and this may translate into a habit [7].

For the unorganised sector the effect on employment has been terrible. A large part of the unorganised sector deals only in unaccounted cash. This has come to a grinding halt and chances are it is a permanent halt. The vacuum left by this type of enterprise will be filled by mainstream enterprise but the switchover will take a long time. The poor will bear the brunt since unemployment will lead to a contraction in wages. The whole process getting employment back on track, in better shape will take at least 24 months. If the demonetizing leads to huge extinguished obligation of the govt in the form of old currency not tendered for exchange or credit, then the govt. will have the 
leeway to alleviate the problems and unemployment through heavy investment in rural infra generating enough employment to offset the effect of demonetization. The turnover of the parallel economy part of which will merge into mainstream economy will keep stock markets buoyant and increase potential future sales of products and services [8].

The employment may be Freeze for some time, say 6 months to 1 year because of little currency in circulation affecting business in every sector. The effects are significantly denied by government on the speech or on the paper. But the reality is not hidden and appears in front off. Many MNCs absorb the temporary employees to complete their moving project and as the demonetizing step bring down. Temporary employees get relieved soon because they can't get salary on time and their contract have been over. Both small and medium scale industries also alleviate the temporary or contract employee and sustain and spotlight on permanent employees. Private sectors run only for profitability and their production gets reduced; they can't bear many employees in their company. There for the crisis of employment is arises in the upcoming days in India [9].

The government's decision to ban Rs 500 and Rs 1,000 currency notes is liable to smack the real estate sector hardest. As a sector that's identified for menace of black money, real estate is now likely to shift towards improved transparency. The move will probably push down property prices, including land prices, down as investors will not be able to utilize their cash in real estate and thereby forcing builders to sell at lower prices. Of the property markets, Delhi-National Capital Region (NCR) is likely to see a hard landing as the market is known for highest involvement of cash component [10].

The practice of investing unaccounted wealth is extensively prevalent in real estate and the government's latest verdict is likely to make things tricky for developers. There can be an increase in projects getting stuck as developers may go slowly on construction given the liquidity stress for them. ${ }^{11}$ Real estate, an overall contributor of $9 \%$ to India's GDP, and one of the most capital- intensive sectors in India, has been the first point of apprehension for investors and consumers across the world, when demonetization was implemented last week. Long queues at ATMs and longer discussions with bank executives are still a veritable feature everywhere in India [11].

A significant objective of demonetization was to reduce the circulation and hoarding of black money. This does not seem the problem with mid-range, affordable residential properties in metro cities. Residential properties that deliver value for money, and those that have always conducted integral and accountable financial transactions in sales, would not be affected. Values of high-end (market price of INR 2 crore, and above) residential properties in non- metro cities and towns would be affected because of large cash transactions. Sufficing to say that as long as transactions are done in transparently, property values would not be affected and primary sales of such residential properties will definitely not be upset [13].

Even though the above scenario, demonetization has led to huge cash deposits by individuals and business owners, thereby increasing inflow of funds into banks, alleviating banks from a liquidity crunch. Conversely, home loan rates are the next in line to be influenced, with such great crests in liquidity. Transparency in accounting, increased inflow of cash into bank accounts, and the ongoing demand for residential investments will influence home loan rates, making them friendlier to buyers. Moreover, though approvals for newer projects will be delayed, existing projects that have received approvals will be able to continue smoothly [14].

The scenario indicates enough evidence of real estate becoming the future of investments and potential moneyparking chests that will reap increasing returns for future generations. Demonetization proved to be good in terms of enabling India to move towards a cashless economy and to transform India through digitization. It may be seen as a radical reform with short term pain and long term gain. Despite some inconvenience, sufferings and problems, it will show positive impact in the long run. It is very difficult to provide for brick and mortar bank within the reach of every villager, and so with the unique advantage of smart phones making cash transfer very easy, it will be easier to solve this problem provided villager change their cheap hand phones and government should provide for cheaper smart phones which will prove to be small price to promote a cashless culture in rural India. It also requires a significant investment in training users and on security from cyber frauds and crimes. There were many who used debit cards, mobile wallets and electronic cash transfer for the first time with a little difficulty but then instances of being helped by techno savvy generation were also common. India is moving to digital banking, many new products, services and systems have popped up wherein there is no need of e-wallet, only mobile number is required to pay an amount upto Rs. 1 lakh per day as declared by Yes bank. There will be an impact on interest rate which should decline by as much as 100 basis points over a period of six months and inflation will go down, which will drive the economy to a new height [15].

This is a time for financial revolution this move of demonetization will boost digital transactions. Demonetization can be seen as building a bridge to digital nation. Strong infrastructure is the foundation of making a digi-India. The government, through a number of regulatory interventions and path breaking reforms, has significantly eliminated bottlenecks to propel the financial sector to a new growth trajectory. The sector has a number of forward and backward industry linkages, so it will result in the development of nation. Demonetization supposed, create increased job opportunities and will contribute to economic growth in the long run. This is also true that in this difficult time, only online players with deep pockets will survive. By 
the time everything gets back to normal, it would have done irreversible damage. The other way of looking things is to stay organized. But most importantly it should not result in survival of the richest and sufferings to the poor [16].

Job losses due to automation have become a cause of concern in recent times. Various reports of the multilateral agencies such as the World Bank Group and the International Labour Organization have cautioned the developed countries, including India, to take appropriate policy measures to minimize the adverse impacts of automation on job opportunities. It is against this backdrop it is pertinent to know what is automation, positive and negative impacts of automation and the possible solutions before the government [17].

The Indian economy is in evolution. The recent initiatives like demonetization and Goods and Services Tax (GST) are so far to deliver the results. Moreover, the technological advancements are pre-conditions to sustain high growth levels in the economy. Every time a new technology integrated into economic processes, it is relatively natural that it leads to anxieties about job losses. Though, the current tendency of automation is a ground of worry due to its impact on even white-collar jobs. Since unemployment is a socio-economic problem, the government, especially the NITI Aayog, should dwell into the issue and come up with a right mix of solution keeping in view the varied interests of the economy as a whole [18].

Initially Government's goal was to restrain black money but if we look at the figure, 97\% of 500 and 1000 rupees' banknotes were deposited in banks and only 3\% (around 43 trillion rupees) black money scraped as undeclared income consequently we can say a less part of Black Money is in cash so this action isn't of use to control black money. However, Tax GDP ratio will increase in future. Due to demonetization counterfeiting currency market discourteous shut down for a even as but they have means to create new notes' duplicate sowe can say in short run their activity slowdown but in long run they can rebuilt their market and also it is easy to handle 2000 rupees notes instead of 1000 rupees notes in briefcase to giving bribe. In this study, we have found some important points about the short-term effects of demonetization as well as about the long-term effects by observing the previous cases of demonetization in other countries [19].

We need to be prepared and attentive to uphold our growth because many countries which have done demonetizations could not sustain the same. In short run, almost all the sector in the Indian economy has been affected negatively due to shorting of cash. However, in long- run Informal Economy would be formalizing. So, government has to focus on informal economy and need to make appropriate policies for them. But, we have got the indication by using the Baumol's model in this case that the transactions were more complex to make than it could be simply estimated by the ratio of money supply in demonetization period to the normal period's money supply [20].
The money supply reduction results to fall in interest rate and accessibility of loan supposed to be easier as interest rate decreases. It was expected to be helpful to new entrepreneur for their start-up. However, after demonetization, Indian economy got the momentum towards Case less economy. Long-term effect of demonetization couldn't identify yet due to less availability of information set [21].

On the midnight of $9^{\text {th }}$ November 2016, India lost $86 \%$ of its monetary base. The print, electronic and social media has been praising Prime Minister's masterstroke by which he has reportedly destroyed the base of corruption in India. In this single move, the Government had attempted to tackle all the three issues affecting the economy i.e. counterfeit currency in circulation, a parallel economy, and terror financing. There is no doubt that Prime Minister has pulled out a major coop and substantially enhanced his reputation as a strong leader [22].

Proposal of demonetization is fine but it has to be taken into deliberation that most of the black money kept in the form of land, buildings or gold or kept abroad. What is in cash constitutes only $4 \%$ of the total amount of black money on which taxes are not being paid. Out of this, a lot of money is in circulation in everyday transaction like if someone is building a house; the bill is not paid through banks for sand, bricks etc. This money goes into the other systems though it has been drawn from bank. These things will come under control with this step [23].

All small farmers, sellers, merchants, daily wage labourers and traders are suffering because of lack of proper planning, intelligence and foresight such as recalibration of ATM machines. There was need to pile up enough of 100 Rupee notes and other smaller denomination notes in the market before taking this step of demonetization. It is being said by critics that this step was taken only to strengthen the likeness of the Prime Minister as he has been incapable to bring on GDP growth, inflation and bringing the black money from abroad [24].

Demonetization is a well-known custom in monetary policy to deal with black money. Our Prime Minister explained why this is a financial surgical strike. It was meant to be suddenly implemented. In the past, demonetization took place twice but failed because the idea is to tackle the black money existing in circulation. This is not tackle corruption per se or the Government is not saying that $100 \%$ corruption will be tackled. If proclamation and time would have been given, this step might not have been flourishing in controlling black money and forged currency in transmission coming from Pakistan, Nepal or other countries [25].

People were facing problems because the limit of withdrawal had not been kept at a higher level. If this would have been kept at a higher level, there were chances that the recycling of black money might begin. The ideal money in 
circulation has to come to the banking channels. It is also being said that what had attempted is replacement of currency and not demonetization itself which was unnecessary. This is a terrible setback for the international standing of the Indian economy. Now, economy is struggling with slowdown. There is demand sluggishness in the economy leading to practically no private sector investment and stagnant industrial growth. If we look at the farm sector, this is the harvest time. Farmers generally deal in cash and India is also largely a cash economy. The cash transactions in this economy are far more than the total number of electronic transactions done on a daily basis. In the tribal heartland of the country, the poor people through middlemen are getting their currencies exchanged for Rs.300 or Rs. 400 because of lack of proper information which is hitting them [26].

However stock of the black economy constitutes a major part of the GDP is momentous. Even if $50 \%$ of this amount withdrawn, the kind of assistance that RBI will get on its liabilities and the sort of deposits commercial banks will get will lead to a rise in the deposit and later on there will be decrease in lending rates plus fiscal deficit. The black money in circulation is like a steroid in the economy which keeps the demand going gives a feeling that everything is working well. The problem is that investment is not taking place in the economy and the rate of growth of capital formation is down. The only way to bring this up is to divert more funds into investments which will happen when the cost of capital comes down [27].

\section{CONCLUSION}

From the above study, it can be simply concluded that employment scenario in the country is not favourable enough to face any confront such as the 'demonetization' of currency. Country like India, when $79 \%$ of non-agricultural wage workers have no written contract and only one fourth are entitled for any social security, the decision is certainly a ground of concern. India has the world largest youth population, so for any developing country like India, it is high time to strap up the population dividend by providing them gainful employment. No doubt, impact of ICT on growth and direct employment is well documented, but its indirect negative employment impact ICT using manufacturing sectors can-not be ignored. Given this, the decision of 'demonetization' will further weaken the already unstable labour market in India. On contrary so far, it can be said that this is a historical step and should be supported by all. One should look at the bigger picture which will definitely fetch results in the long term. This is what the people have been asking for a long time which has finally happened.

\section{REFERENCES}

[1] Ghumman, G. S. (2009). Are de jure labor laws absolute? Formal manufacturing in India. Singapore Management University (Singapore).

[2] Mwiche, D. (2012). Social security coverage for urban informal sector workers: the case study of the Copper belt of Zambia (Doctoral dissertation, Master of Business Administration (MBA); 2005).

[3] Poschen, P. (2017).Decent work, green jobs and the sustainable economy: solutions for climate change and sustainable development. Routledge.

[4] Anand, R., \& Tulin, V. (2014). Disentangling India's Investment Slowdown (No. 14-47). International Monetary Fund.

[5] Hull, J. C., \& Basu, S. (2016). Options, futures, and other derivatives. Pearson Education India.

[6] Poschen, P. (2017). Decent work, green jobs and the sustainable economy: solutions for climate change and sustainable development. Routledge.

[7] Alexander, C., \& Reno, J. (Eds.). (2012). Economies of recycling: the global transformation of materials, values and social relations. Zed Books Ltd..

[8] Krugman, P. R. (1997). The age of diminished expectations: US economic policy in the 1990s. MIT press.

[9] Tiwari, P., \& Rao, J. (2017). Delhi's Changing Built Environment. Routledge.

[10] Hagel, J., \& Singer, M. (1999). Net worth: shaping markets when customers make the rules. Harvard Business Press.

[11] Shirley, M. A. J. (2017). Impact of Demonetization in India. International Journal of Trend in Research and Development, 20-23.

[12] Mahajan, P., \& Singla, A. (2017). Effect of demonetization on financial inclusion in India. 6th International Conferenec on Recent Trends in Engineering, Science and Management. Available at: www. conferenceworld. in.

[13] Dubey, M. (2018). Black money and its impact on Indian economy. International Journal of Trend in Scientific Research and Development, 2(5), 2068-2073.

[14] Khetal, M. P. (2018). Digital India's SME's economy - Switching to digital is a necessity not a choice. International Journal of Trend in Scientific Research and Development, Special Issue (Special IssueICDEBI2018), 150-153.

[15] Impact of economic slowdown on Indian agriculture. (2020). Indian Journal of Economics and Development, 457-461. https://doi.org/ 10.35716/ ijed/ns20-036

[16] Mander, J. (Ed.). (2014). The case against the global economy: and for a turn towards localization. Routledge.

[17] Aggarwal, N., \& Narayanan, S. (2017). Impact of India's demonetization on domestic agricultural markets. SSRN Electronic Journal.

[18] Hall, I. (2018). Our time has come: How India is making its place in the world. International Affairs, 94(3), 688-689.

[19] Sharma, P. (2017). Kranti Nation: India and the Fourth Industrial Revolution. Pan Macmillan.

[20] Shirley, M. A. J. (2017). Impact of Demonetization in India. International Journal of Trend in Research and Development, 20-23.

[21] Aggarwal, N., \& Narayanan, S. (2017). Impact of India's demonetization on domestic agricultural markets. SSRN Electronic Journal.

[22] Govil, S. (2017). Demonetization and Its Impact On Indian Economy. Journal of Management Value and Ethics, 7(1).

[23] Mendonca, V., \& Jain, R. (2019). Boom country? The new wave of Indian enterprise. Vikalpa: The Journal for Decision Makers, 44(1), 55-57.

[24] K, A. (2018). Demonetisation and its impact on Indian economy. International Journal of Research in Arts and Science, 04(02), 04-05.

[25] Thomas, J. J. (2017). Economic growth without employment. Employment Policy in Emerging Economies, 83-101.

[26] Lahiri, A. (2020). The great Indian demonetization. Journal of Economic Perspectives, 34(1), 55- 74. 